\title{
KEDUDUKAN UNDANG-UNDANG DAN PERPPU DALAM PERSPEKTIF PENAFSIRAN HUKUM TATA NEGARA
}

\section{Dadin Eka Saputra ${ }^{1}$}

\begin{abstract}
It is stated in the fourth amendment of 1945 constitution in Article 24 C (1) that the Constitutional Court have the power to have final decision/ judgment at first and last level to examine Law toward Constitution, to decide the dispute of authority of state institutions granted by the Constitution, the dissolution of political parties, and the dispute as the results of the elections. Around this time, there are a lot of the problems, especially in the interpretation of the authority given to the Constitutional Court by the Constitution in order to examine the Law against the Constitution, if it is associated with Law No. 12 of 2011 on the Establishment of Regulatory of Law, article 7 (1) which states that the type and hierarchy of legislation consists of: a) Constitution of Republic of Indonesia of 1945; b) Decree of the People's Consultative Assembly; c) Laws/Government Regulation substitute of Law; d) Government Regulation; e) Presidential Decree; f) Provincial Regulation; and g) Regulation of City/District. Therefore, deep analysis study about interpretation of Laws and Government Regulation of substituting law in terms of theories of Constitutional Law is required.
\end{abstract}

\begin{abstract}
Abstrak : Di dalam Undang-Undang Dasar 1945 hasil perubahan ke empat sebagaimana yang termuat didalam pasal $24 \mathrm{C}$ ayat (1) yang menyebutkan bahwa Mahkamah Konstitusi berwenang mengadili pada tingkat pertama dan terakhir yang putusannya bersifat final untuk menguji undang-undang terhadap Undang-Undang Dasar, memutus sengketa kewenangan lembaga Negara yang kewenangannya diberikan oleh Undang-Undang Dasar, memutus pembubaran partai politik, dan memutus perselisihan hasil pemilihan umum. Dengan adanya hal ini maka munculah banyak problematika khususnya di dalam penafsiran mengenai kewenangan yang diberikan kepada Mahkamah Konstutusi oleh Undang-Undang Dasar guna untuk menguji Undang-Undang terhadap Undang-Undang Dasar, jika dikaitkan dengan Undang-Undang Nomor 12 tahun 2011 tentang Pembentukan Peraturan Perundangan-Undangan pasal 7 ayat (1) yang menyatakan bahwa jenis dan hierarki Peraturan Perundang-
\end{abstract}

1 Dosen Fakultas Syariah dan Ekonomi Islam IAIN Antasari Banjarmasin dan Praktisi Hukum Advokat (PERRADI). 
undangan terdiri atas : a). Undang-Undang Dasar Negara Republik Indonesia Tahun 1945, b). Ketetapan Majelis Permusyawaratan Rakyat, c). UndangUndang/Peraturan Pemerintah Pengganti Undang-Undang, d). Peraturan Pemerintah, e). Peraturan Presiden, f). Peraturan Daerah Provinsi dan, g). Peraturan Daerah Kota/Kab, maka perlu adanya pengakajian analisis yang mendalam tentang penafsiran Undang-Undang dan Peraturan Pemerintah Pengganti Undang-Undang ditinjau dari teori-teori Hukum Tata Negara.

Kata kunci : Penafsiran, Kedudukan, Undang-Undang, Perpu, teori-teori Hukum Tata Negara

\section{Pendahuluan}

Negara Indonesia adalah negara hukum. Hal ini dinyatakan secara tegas di dalam Pasal 1 ayat (3) Undang-Undang Dasar Negara Republik Indonesia 1945 (selanjutnya disingkat UUD NRI 1945) pasca amandemen. Sebagai negara hukum maka hukum harus dipahami sebagai satu kesatuan sistem ang terdiri dari elemen-elemen kelembagaan (institusional), kaedah aturan (instrumental) dan perilaku para subyek hukum (elemen subyektif dan cultural). Ketiga elemen sistem hukum tersebut mencakup; kegiatan pembuatan hukum (law making), kegiatan pelaksanaan hukum atau penerapan hukum (law administration) dan kegiatan peradilan atas pelanggaran hukum (law adjudicating) atau yang biasa disebut dengan penegakkan hukum dalam arti sempit (law enforcement). ${ }^{2}$

Indonesia sebagai negara hukum modern (welfare state) dalam rangka mewujudkan tujuan negara yakni memberikan kesejahteraan bagi masyarakatnya dan melindungi hak-hak warga negaranya, harus menganut prinsip utama atau asas pokok yang terdiri atas asas legalitas, asas pengakuan dan perlindungan hak asasi manusia, asas pembagian kekuasaan negara, asas peradilan yang bebas dan tidak memihak, asas kedaulatan rakyat, asas demokrasi dan asas konstitusional. ${ }^{3}$

Makna atau nilai dari asas negara hukum tersebut adalah bahwa hukum merupakan sumber tertinggi (supremasi) dalam mengatur dan menentukan mekanisme hubungan hukum antara negara dan masyarakat, maupun antara anggota atau kelompok masyarakat yang satu dengan yang lainnya dalam mewujudkan tujuannya.

Pemerintah (bestuur) selaku pelaksana kebijakan politik negara mempunyai wewenang sebagimana diberikan oleh peraturan perundang-undangan yang berlaku atau berdasarkan pada asas legalitas untuk mengendalikan pemerintahan,

2 Jimly Asshidiqie, Konstitusi dan Ketatanegaraan Indonesia Kontemporer, Penerbit The Biography Institute, Jakarta, 2007, hlm. 131.

3 Imran Juhaefah, Hal Ihwal Kegentingan Yang Memaksa Sebagai Landasan Pembentukan Peraturan Pemerintah Pengganti Undang-Undang, Disertasi, Pascasarjana Universitas Muslim Indonesia, Makassar, 2011, hlm. 2. 
memimpin atau mengatur warga negaranya, memberi petunjuk, menggerakkan potensi, memberi arah, mengkoordinasikan kegiatan, mengawasi, mendorong dan melindungi masyarakat. ${ }^{4}$

Dalam praktik penyelenggaraan negara atau pemerintahan sering terjadi hal-hal yang tidak normal dalam menata kehidupan kenegaraan, di mana sistem hukum yang biasa digunakan tidak mampu mengakomodasi kepentingan negara atau masyarakat sehingga memerlukan pengaturan tersendiri untuk menggerakkan fungsi-fungsi negara agar dapat berjalan secara efektif guna menjamin penghormatan kepada negara dan pemenuhan hak-hak dasar warga negara. Dengan demikian maka penggunaan perangkat hukum biasa sejak semula haruslah mengantisipasi berbagai kemungkinan keadaan yang bersifat tidak normal agar negara dapat menjamin kelangsungan hidup berbangsa dan bernegara.

Untuk mengantisipasi keadaan tersebut, maka di Indonesia secara konstitusional telah diletakkan pengaturannya dalam Pasal 22 UUD 1945, sebagai berikut: (1) dalam hal ihwal kegentingan yang memaksa, Presiden berhak menetapkan Peraturan Pemerintah Pengganti Undang-Undang; (2) Peraturan Pemerintah harus mendapat persetujuan Dewan Perwakilan Rakyat dalam persidangan berikut, (3) jika tidak mendapat persetujuan maka Peraturan Pemerintah itu harus dicabut.

Ketentuan sebagaimana dimaksud dalam ayat (1) tersebut di atas sangat diperlukan agar keselamatan negara dapat dijamin oleh pemerintah, yang memaksa pemerintah untuk bertindak cepat dan tepat. Meskipun demikian pemerintah tidaklah bebas membentuk Peraturan Pemerintah Pengganti UndangUndang (PERPPU) karena pemerintah tetap tidak terlepas dari pengawasan Dewan Perwakilan Rakyat. Permasalahan yang muncul, dan seringkali menjadi bahan perdebatan di sejumlah kalangan ahli hukum maupun politik adalah parameter dari suatu keadaan yang dapat dikualifikasi sebagai "kegentingan yang memaksa". Beberapa PERPPU yang pernah dikeluarkan oleh Presiden yakni salah satunya adalah Perppu Nomor 1 tahun 2014 yaitu tentang Pemilihan Kepala Daerah di mana Perppu ini dibuat oleh kekuasaan eksekutif untuk merubah atau menggantikan Undang-Undang Nomor 22 Tahun 2014 tentang Pemilihan Kepala Daerah yang ternyata juga menimbulkan polemik di masyarakat. Perbedaan prinsip pada PERPPU Nomor 1 Tahun 2014 atau PERPPU Pilkada tersebut adalah perubahan mekanisme pemilihan kepala daerah yang sebelumnya pada UU Nomor 22 Tahun 2014 mengatur mekanisme pemilihan kepala daerah secara tidak langsung melalui Dewan Perwakilan Rakyat Daerah (DPRD), dirubah atau diganti dalam PERPPU Pilkada tersebut mekanisme pemilihan kepala daerah adalah menjadi secara langsung. Termasuk juga PERPPU No. 2 Tahun 2014 tentang Pemerintahan Daerah yang beleid perubahan atas UU No. 23 Tahun 2014 tentang Pemerintahan Daerah yang menghapus wewenang DPRD untuk memilih kepala daerah.

4 Muin Fahmal, Peran Asas-asas Umum Pemerintahan Yang Layak Dalam Mewujudkan Pemerintahan Yang Bersih, Penerbit Kreasi Total Media, Yogyakarta, 2008, hlm. 100. 
Di dalam Undang-Undang Dasar 1945 hasil amandemen kita sekarang ini acapkali mengalami banyak sekali kendala maupun perdebatan sengit dan juga multitafsir di antara para pakar maupun para ahli-ahli hukum yang mencoba memberikan penafsiran-penafsiran pasal-pasal atau ayat-ayat yang ada di dalam Undang-Undang Dasar 1945, salah satu gambaran yang nyata adalah tentang dikeluarkannya PERPPU Nomor 1 Tahun 2014 tentang Pemilihan Gubernur, Bupati Dan Walikota tersebut di atas yang merupakan pemahaman dari Pasal 22 UUD 1945 dan ketentuan di dalam bab VIIB UUD 1945 tentang pemilihan umum pasal 22E ayat (2) yang menyebutkan bahwa "pemilihan umum diselenggarakan untuk memilih anggota Dewan Perwakilan Rakyat, Dewan Perwakilan Daerah, Presiden dan Wakil Presiden dan Dewan Perwakilan Rakyat Daerab".

Akan tetapi di dalam UUD 1945 kita tidak mengatur secara eksplisit tentang lembaga negara yang berhak mengadili maupun menguji ketentuan konstitusional yang dinamakan dengan Peraturan Pemerintah Pengganti Undang-Undang tersebut, karena sesuai dengan bunyi pasal 24A ayat (1) bahwa "Mabkamah Agung berwenang mengadili pada tingkat kasasi, mengüi peraturan perundangundangan di bawah undang-undang terhadap undang-undang, dan mempunyai wewenang lainnya yang diberikan oleh undang-undang". Dan juga ketentuan di dalam pasal 24C ayat (1) bahwa "Mabkamah Konstitusi berwenang mengadili pada tingkat pertama dan terakhiryang putusannya bersifat final untuk. menguji undang-undang terhadap UndangUndang Dasar, memutus sengketa kewenangan lembaga Negara yang kewenangannya diberikan oleh Undang-Undang Dasar, memutus pembubaran partai politik, dan memutus perselisiban tentang hasil pemilihan umum".

Permasalahan ini akan menjadi semakin kompleks jika dikaitkan dengan Undang-Undang Nomor 12 tahun 2011 tentang Pembentukan Peraturan Perundang-undangan, di dalam ketentuan pasal 7 ayat (1) yang menyebutkan bahwa "Jenis dan hierarki Peraturan Perundang-undangan terdiri atas : a. UndangUndang Dasar Negara Republik. Indonesia tahun 1945, b. Ketetapan Majelis Permusyawaratan Rakyat, c. Undang-Undang/Peraturan Pemerintah Pengganti UndangUndang, d. Peraturan Pemerintah, e. Peraturan Presiden, f. Peraturan Daerah Provinsi, g. Peraturan Daerah Kabupaten/Kota”. Di dalam Undang-Undang tersebut pembuat undang-undang memposisikan PERPPU sejajar dengan undang-undang padahal sebagaimana kita ketahui bahwa eksistensi PERPPU tidaklah secara utuh dan kompleks diatur di dalam Undang-Undang Dasar 1945, yaitu tentang lembaga negara yang berhak mengadili maupun mengujinya dan juga yang menjadi pertanyaan mendasar apakah PERPPU ini adalah sebuah produk hukum murni dari eksekutif ataukah sebuah produk hukum dari eksekutif yang dibahas secara bersama-sama dengan lembaga legislatif.

\section{Rumusan Masalah}

Dari uraian tersebut di atas maka peneliti merumuskan permasalahan yang akan di bahas yaitu, bagaimana kedudukan undang-undang dan PERPPU dalam perspektif penafsiran hukum tata negara? 


\section{Tujuan Penelitian}

Penelitian ini bertujuan untuk menganalisis kedudukan undang-undang dan perppu dalam perspektif penafsiran hukum tata negara.

\section{Metode Penelitian}

Metode penelitian yang digunakan dalam penelitian ini adalah yuridis normatif, yaitu penelitian yang dalam pengkajiannya dengan mengacu dan mendasarkan pada norma-norma dan kaidah-kaidah hukum, peraturan perundang-undangan yang berlaku, teori-teori dan doktrin hukum, yurisprudensi, dan bahan-bahan kepustakaan lainnya yang relevan dengan topik penelitian.

Pengumpulan bahan hukum dilakukan dengan studi pustaka yakni melalui pengakajian terhadap UUD Negara Republik Indonesia Tahun 1945 dan berbagai pustaka yang relevan dengan objek penelitian.

Pendekatan yang digunakan dalam penelitian ini adalah pendekatan yuridis, yakni menganalisis permasalahan tentang kedudukan undang-undang dan perppu dalam perspektif penafsiran hukum tata negara.

\section{Teori-teori ilmu hukum tata negara}

Negara merupakan gejala kehidupan umat manusia di sepanjang sejarah umat manusia. Konsep negara berkembang mulai dari bentuknya yang paling sederhana sampai ke yang paling kompleks di zaman sekarang. Sebagai bentuk organisasi kehidupan bersama dalam masyarakat, Negara selalu menjadi pusat perhatian dan objek kajian bersamaan dengan berkembangnya ilmu pengetahuan umat manusia. Banyak cabang ilmu pengetahuan yang menjadikan Negara sebagai objek kajiannya. Misalnya, ilmu politik, ilmu negara, ilmu hukum kenegaraan, ilmu hukum tata negara, hukum administrasi negara, dan ilmu administrasi pemerintahan (Public Administration), semuanya menjadikan negara sebagai pusat perhatiannya.

Namun demikian, apa sebenarnya yang diartikan orang sebagai negara tentulah tidak mudah untuk didefinisikan. Meskipun diakui merupakan istilah yang sulit didefinisikan, O. Hood Philips, Paul Jackson, dan Patricia Leopold mengartikan negara atau state sebagai : "An independent political society occupying a defined territory, the members of which are united together for the purpose of resisting external force and the preservation of internal order ". 5

Dikatakan pula oleh Philips, Jackson, dan Leopold:

"No independent political society can be terned as state unless it professes to exercise both these functions: but no modern state of any importance contents it self with this narrow range of activity. As civilisationm becomes more complex, population increases and social conscience arises, the needs of the governed call for increased attention; taxes have to be livied

5 O.Hood Philips, Paul Jackson and Patricia Leopold, Constitutional and Administration Law, $8^{\text {th }}$ edition, (London: Sweet and Maxwell, 2001), hlm. 4. 
to meet these needs; justice must be administered, commere regulated, educational facilities and many other social services provided " 6

Selanjutnya dikemukakan juga oleh ketiga sarjana Inggris tersebut:

"A fully developed modern state is experted to deal with a vast mass of social problems, either by direct activity or by supervision, or regulation. In order to carry out these functions, the state must have agents or organs through which to operate. The appointment or establishment of these agents or organs, the general nature of their functions and powers, their relations inter and between them and the private citizen, form a large part of the constitution of a state".

Secara sederhana, oleh para sarjana sering diuraikan adanya 4 (empat) unsur pokok dalam setiap negara, ${ }^{8}$ yaitu (i) a definite territory, (ii) population, (iii) a government, dan (iv) sovereignity. Namun demikian, untuk menguraikan pengertian negara dalam tataran yang lebih filosofis, dapat pula merujuk kepada pendapat Hans Kelsen dalam bukunya "General Theory of Law and State" 9 yang menguraikan pandangannya tentang negara atau state a juristic entity dan states as a politicaly organized society atau state as power.

Ilmu hukum tata negara adalah salah satu cabang ilmu hukum yang secara khusus mengkaji persoalan hukum dalam konteks kenegaraan. Kita memasuki bidang hukum tata negara, menurut Wirjono Prodjodikoro, apabila kita membahas norma-norma hukum yang mengatur hubungan antara subjek hukum orang atau bukan orang dengan sekelompok orang atau badan hukum yang berwujud negara atau bagian dari negara. ${ }^{10}$ Dalam bahasa Perancis, hukum tata negara disebut Droit Constitutionnel atau dalam bahasa Inggris disebut Constitutional Law. Dalam bahasa Belanda dan Jerman, hukum tata negara disebut Staatsrecht, tetapi dalam bahasa Jerman sering juga dipakai istilah verfassungrecht (hukum tata negara) sebagai lawan perkataan verwaltungsrecht (hukum administrasi negara).

Dalam bahasa Belanda, untuk perkataan hukum tata negara juga biasa dipergunakan istilah staatsrecht atau hukum negara (state law). Dalam istilah staatsrecht itu terkandung 2 (dua) pengertian, yaitu staatsrecht in ruimere zin (dalam arti luas), dan staatsrecht in engere zin (dalam arti sempit). Staatsrecht in engere zin atau Hukum Tata Negara dalam arti sempit itulah yang biasanya disebut Hukum Tata Negara atau Verfassungrecht yang dapat dibedakan antara pengertian yang luas dan yang sempit. Hukum Tata Negara dalam arti luas (in rumere zin)

6 Ibid., hlm. 4-5.

7 Ibid., hlm. 5.

8 A. Appadoral, The Substance of Politics, (India: Oxford University Press, 2005), hlm. 11.

9 Hans Kelsen, General Theory of Law and State, (New York: Russel and Russel, 1961), hlm. 188-191.

${ }^{10}$ Wirjono Prodjodikoro, Asas-Asas Hukum Tata Negara di Indonesia, cet. Keenam, (Jakarta: Dian Rakyat, 1989), hlm.2. 
mencakup Hukum Tata Negara (verfassungrecht) dalam arti sempit dan Hukum Administrasi Negara (verwaltungsrecht). ${ }^{11}$

Istilah "Hukum Tata Negara" dapat dianggap identik dengan pengertian "Hukum Konstitusi" yang merupakan terjemahan langsung dari perkataan Constitutional Law (Inggris), Droit Constitutionel (Perancis), Dirrito Constitutionale (Italia), atau Verfassungsrecht (Jerman). Dari segi bahasa, istilah Constitutional Law dalam bahasa Inggris memang biasa diterjemahkan sebagai "Hukum Konstitusi". Namun, istilah "Hukum Tata Negara" itu sendiri jika diterjemahkan ke dalam bahasa Inggris, niscaya perkataan yang dipakai oleh Constitutional Law. ${ }^{12}$ Oleh karena itu, Hukum Tata Negara dapat dikatakan identik atau disebut istilah lain belaka dari "Hukum Konstitusi". ${ }^{13}$

J.H.A Logemann, dalam bukunya "Staatsrecht", membedakan antara formeele stelselmatigheid dan materieele stelselmatigheid. ${ }^{14}$ Istilah yang pertama adalah hukum tata negara, sedangkan yang kedua adalah asas-asas hukum tata negara. Perbedaan keduanya seakan-akan adalah perbedaan antara bentuk dan isi, antara vorm en inhoud, atau antara stelsel en beginsel. Vorm adalah bentuk, sedangkan inhoud adalah isinya. Beginsel adalah asas-asasnya, sedangkan stelsel adalah pelembagaannya. Istilah vorm en Inhoud dipakai oleh Van Vollenhoven seperti dalam Vorm en Inhoud van het Internationale Recht. ${ }^{15}$ Sedangkan Ter Haar Bezn menggunakan istilah beginsel en stelsel seperti dalam Beginsel en Stelsel van bet Adatrecht. ${ }^{16}$

Demikian pula konstitusi yang menjadi objek kajian hukum tata negara juga mempunyai tiga pengertian, yaitu $:^{17}$

a. Constitutie in materiele zin dikualifikasikan karena isinya (gequalificerd naar de inhoud), misalnya berisi jaminan hak asasi, bentuk Negara, dan fungsifungsi pemerintahan, dan sebagainya;

${ }^{11}$ Moh Kusnardi dan Harmaily Ibrahim, Pengantar Hukum Tata Negara Indonesia, cet. Kelima, (Jakarta: Pusat Studi Hukum Tata Negara Fakultas Hukum Universitas Indonesia, 1983), hlm. 22.

${ }^{12}$ Lihat dan Bandingkan Sri Soemantri, Susunan Ketatanegaraan Menurut UUD 1945 dalam Ketatanegaraan Indonesia Dalam Kehidupan Politik. Indonesia, (Jakarta: Sinar Harapan, 1993), hlm. 29. Lihat juga dalam Miriam Budiardjo, Dasar-DasarIlmu Politik, (Jakarta; Gramedia Pustaka Tama, 1992), hlm. 95.

${ }^{13}$ Lihat dan Bandingkan pula pendapat dari Bagir Manan yang membedakan antara Konstitusi (UUD) dengan Hukum Kostitusi (Hukum Tata Negara). Lihat Bagir Manan, Perkembangan UUD 1945, (Yogyakarta: FH-UII Press, 2004), hlm. 5.

${ }^{14}$ Moh. Kusnardi dan Bintan R. Saragih, Ilmu Negara, edisi revisi, Jakarta: Gaya Media Pratama, 2000), hlm.10.

${ }^{15}$ Christian van Vollenhoven, H.D. Tjenk Willink \& Zoon, (Haarlem: Martinus Nyhoof \& Gravenhage, 1934).

${ }^{16}$ Lihat terjemahan Soebakti Poesponoto, Asas dan Susunan Hukum Adat, (Jakarta: Pradnya Paramita, 1992).

${ }^{17}$ Ibid. 
b. Constitutie in formele zin, dikualifikasikan karena pembuatnya (gequalificerd naar de maker), misalnya oleh MPR;

c. Naskah Grondwet, sebagai geschreven document, misalnya harus diterbitkan dalam Lembaran Negara, voor de bewijsbaarbeid en voor de stabiliteit sebagai satu kesatuan rujukan, yaitu sebagai naskah kenegaraan yang penting atau belangrijke staatkundige stukeken.

\section{Penafsiran Hukum dalam Teori Hukum Tata Negara}

Penafsiran merupakan kegiatan yang sangat penting dalam hukum. Penafsiran merupakan metode untuk memahami makna yang terkandung dalam teks-teks hukum untuk dipakai dalam menyelesaikan kasus-kasus atau mengambil keputusan atas hal-hal yang dihadapi secara konkrit. Di samping hal itu, dalam bidang hukum tata negara, penafsiran dalam hal ini judicial interpretation (penafsiran oleh hakim), juga dapat berfungsi sebagai metode perubahan konstitusi dalam arti menambah, mengurangi, atau memperbaiki makna yang terdapat dalam suatu teks Undang-Undang Dasar. Seperti dikemukakan oleh K.C. Wheare, Undang-Undang Dasar dapat diubah melalui (i) formal amandement, (ii) judicial interpretation, dan (iii) constitutional usage and conventions. ${ }^{18}$

Dikarenakan pentingnya hal tersebut diatas, maka dalam setiap buku teks ilmu hukum lazim diuraikan adanya berbagai metode penafsiran. Banyak sarjana hukum yang membagi metode penafsiran ke dalam 5 (lima) macam metode penafsiran, dan 3 (tiga) macam metode konstruksi. Dalam hal ini, metode konstruksi dianggap tidak termasuk ke dalam pengertian penafsiran. Tetapi, ada pula sarjana yang menganggap metode konstruksi itu tiada lain merupakan varian saja atau termasuk bentuk lain dari metode penafsiran juga, sehingga macam dan jenis metode penafsiran itupun dikelompokkan secara berbeda dari sarjana lainnya. ${ }^{19}$

Para pakar hukum telah menguraikan adanya 9 (sembilan) teori penafsiran yang berbeda penggambarannya dari apa yang dikemukakan oleh Arief Sidharta. Kesembilan teori penafsiran tersebut adalah: ${ }^{20}$

${ }^{18}$ Ph. Visser't Hoft, Penemuan Hukum, judul asli Rechtsvinding, diterjemahkan oleh B. Arief Sidharta, (Bandung: Laboratorium Hukum FH Univ Parahyangan, 2001), hlm.25.

19 Jimly Asshidiqie, Teori \& Aliran Penafsiran Hukum Tata Negara, cet. I, Jakarta: Ind. Hill Co.,1997), hlm. 17-18.

${ }^{20}$ Lihat dan bandingkan pendapat sarjana yang memasukkan metode interpretasi (penafsiran) sebagai salah satu metode dalam penemuan hukum yang dilakukan dengan cara Interpretasi Gramatikal (kebahasaan). Sistematis (logis), Historis, dan Teleologis (sosiologis). Lihat, misalnya, Bambang Sutiyoso dan Sri Hastuti, Aspek-Aspek Perkembangan Kekuasaan Kehakiman di Indonesia, (Yogyakarta: UII Press, 2005), hlm. 131-134. 
1. Teori penafsiran letterlijk atau harfiah (what does the word mean?)

Penafsiran yang menekankan pada arti atau makna kata-kata yang tertulis. Misalnya, kata servants dalam Konstitusi Jepang Art. 15 (2), "All public officials are servants of the whole community and not of any group thereof". Contoh lain mengenai kata a natural association dalam Art. 29 ayat (1) dan kata the moral dalam ayat (2) konstitusi Italia yang menyatakan :

"(1) The Republic recognizes the rights of the family as a natural association founded on marriage; (2) Marriage is based on the moral and legal equality of the spouses, within the limits laid down by law to safeguard the unity of the family".

Contoh berikutnya lagi, misalnya terlihat pada kata inconsistent dalam ayat (1) Article 13 Konstitusi India, yaitu :

"All always in force in the territory of India immediately before the commencement of this Constitution, in so far as they are inconsistent with the provisions of this part, shall, to the extent of such inconsistency, be void'.

2. Teori penafsiran gramatikal atau interpretasi bahasa (what does it linguistically mean?)

Penafsiran yang menekankan pada makna teks yang di dalamnya kaidah hukum dinyatakan. Penafsiran dengan cara demikian bertolak dari makna menurut pemakaian bahasa sehari-hari atau makna teknis-yuridis yang lazim atau dianggap sudah baku. ${ }^{21}$ Menurut Vissert't Hoft di negaranegara yang menganut tertib hukum kodifikasi, maka teks harfiah undangundang sangat penting. Namun, penafsiran gramatikal saja dianggap tidak mencukupi, apalagi jika mengenai norma yang hendak ditafsirkan itu sudah menjadi perdebatan. ${ }^{22}$

3. Teori penafsiran historis (what is historical background of the formulation of a text)

Penafsiran historis mencakup dua pengertian : (1) penafsiran sejarah perumusan undang-undang; dan (ii) penafsiran sejarah hukum. Penafsiran yang pertama, memfokuskan diri pada latar belakang sejarah perumusan naskah. Bagaimana perdebatan yang terjadi ketika naskah itu hendak

${ }^{21}$ Ph. Visser;t Hoft, Penemuan Hukum, judul asli Rechtsvinding, diterjemahkan oleh B. Arief Sidharta, (Bandung: Laboratorium Hukum FH Univ. Parahiayangan, 2001), hlm. 25 .

${ }^{22}$ Ibid., hal 26. Misalnya, basis sistem ekonomi sosialis Cina, seperti dalam Art. 6 ayat (1) Konstitusi Cina: (1) "The basis of the socialist economic system of the People's Republic of China is socialist public ownership of the means of production, namely, ownership by the whole people and collective ownership by the working people". Dan makna dari sistem kepemilikan public, seperti dalam Art 6 ayat (2) "The system of socialist public ownership supersedes the system of exploitation of man by man; it applies the principle of from each according to his ability, to each according to his work". 
dirumuskan. Oleh karena itu yang dibutuhkan adalah kajian mendalam tentang notulen-notulen rapat, catatan-catatan pribadi peserta rapat, tulisan-tulisan peserta rapat yang tersedia baik dalam bentuk tulisan ilmiah maupun komentar tertulis yang pernah dibuat, otobiografi yang bersangkutan, hasil wawancara yang dibuat oleh wartawan dengan yang bersangkutan, atau wawancara khusus yang sengaja dilakukan untuk keperluan menelaah peristiwa yang bersangkutan. Penasiran kedua, mencari makna yang dikaitkan dengan konteks kemasyarakatan masa lampau. Dalam pencarian makna tersebut juga kita merujuk pendapat-pendapat pakar dari masa lampau, termasuk pula merujuk kepada norma-norma hukum masa lalu yang masih relevan. ${ }^{23}$

4. Teori penafsiran sosiologis (what does social context of the event to be legally judged)

Konteks sosial ketika suatu naskah dirumuskan dapat dijadikan perhatian untuk menafsirkan naskah yang bersangkutan. Peristiwa yang terjadi dalam masyarakat acapkali mempengaruhi legislator ketika naskah hukum itu dirumuskan. Misalnya pada kalimat "dipilih secara demokratis" dalam Pasal 18 ayat (4) Undang-Undang Dasar 1945 yang menyatakan, "Gubernur, Bupati, dan Walikota masing-masing sebagai kepala pemerintah daerah provinsi, kabupaten, dan kota dipilih secara demokratis."

5. Teori penafsiran sosio-historis (asbabunnuzul dan asbabulwurud, what does the social context behind the formulation of the text)

Berbeda dengan penafsiran sosiologis, penafsiran sosio-historis memfokuskan pada konteks sejarah masyarakat yang mempengaruhi rumusan naskah hukum. Misalnya, ide persamaan dalam konteks konstitusi Republik V Perancis, ${ }^{24}$ ide ekonomi kekeluargaan dalam Pasal 33 UUD 1945, dan ide Negara Kekaisaran Jepang. ${ }^{25}$

6. Teori penafsiran filosofis (what is philosophical thought behind the ideas formulated in the text)

Penafsiran dengan focus perhatian pada aspek filosofis. Misalnya, ide Negara hukum dalam kostitusi Republik V Perancis Article 66 : "No person may be detained arbitrarily". Ide Negara hukum dalam Pasal 1 ayat

${ }^{23}$ Ibid., hlm.29.

${ }^{24}$ Constitution of The Fifth French Republic, 1958, Article 2, "France is an indivisible, secular, democratic and Sosial Republic. It shall insure equality before the law for all citizens without distinction of origin, race, or religion. It shall respect all beliefs.."

25 Art. 1 (Symbol of State): "The Emperor shall be the symbol of the State and of the unity of the people, deriving his position from the will of the people with whom resides sovereign power". Article 2 (Dysnatic Throne): "The Imperial Throne shall be dysnatic and succeeded to in accordance with the Imperial House Law Passed by The Diet". 
(3) Undang-Undang Dasar Republik Indonesia Tahun 1945 yang menyatakan bahwa Negara Indonesia adalah negara hukum. Contoh lain lagi adalah rumusan ide demokrasi terpusat (centralized democrasy) dalam Konstitusi Cina. ${ }^{26}$

7. Teori penafsiran teleologis (what does the articles would like to achieve by the formulated text)

Penafsiran ini difokuskan pada penguraian atau formulasi kaidah-kaidah hukum menurut tujuan dan jangkauannya. Tekanan tafsiran pada fakta bahwa pada kaidah hukum terkandung tujuan atau asas sebagai landasan dan bahwa tujuan dan atau asas tersebut mempengaruhi interpretasi. Dalam penafsiran demikian juga diperhitungkan konteks kenyataan kemasyarakatan yang aktual. ${ }^{27}$

8. Teori penafsiran holistik.

Penafsiran ini mengaitkan suatu naskah hukum dengan konteks keseluruhan jiwa dari naskah tersebut. Misalnya, The individual economy ${ }^{28}$ dalam Article 11 ayat (1) Konstitusi Cina :

(1) "The individual economy of urban and rural working people, operated within the limits prescribed by law, is a complement to the socialist public economy. The state protects the lawful rights and interest of the individual economy", (2) "The state guides, helps, and supervises the individual economy by exercising administrative control", (3) "The state permits the private sector of the economy to exist and develop within the limits prescribed by law. The private sector of the economy is a complement to the socialist public economy. The state protects the lawful rights and interest of the private sector of the economy, and exercises guidance, supervision and control over the private sector of the economy."

${ }^{26}$ Konstitusi Cina, Article 3 (Democratic Centralism) : “(1) The state organs of the People”s Republic of China apply the principle of democratic centralism. (2) The National People's Congress and the Local people's congresses at different levels are instituted through democratic election. They are responsible to the people and subject to their supervison. (3) All administrative, judicial and procuratorial organs of the state are created by the people'scongress to which they are responsible and under whose supervision they operate. (4) The division of functions and powers between the central and local state organs is guided by the principle of giving full play to the initiative and enthusiasm of the local authorities under the unified leadership of the central authorities."

${ }^{27}$ Visser't Hoft, Op. Cit., hlm. 30.

${ }^{28}$ Istilah the individual economy dalam konteks Negara sosialis yang dianut Cina menjadi jiwa dari sistem sosialis, seperti yang dinyatakan dalam konstitusi Cina, Article (1) "The People's Republic of China is a socialist state under the people's democratic dictatorship led by the working class and based on the alliance of workers and peasants"; (2) "The socialist system is the basic system of The People's of China. Sabotage of the socialist system by any organization or individual is probibited". 
9. Teori penafsiran holistik tematis-sistematis (what is the theme of the articles formulated, or how to understand the articles systematically according to the grouping of the formulation).

Dalam hal ini, misalnya, regular election dalam Article 68 dan 69 Kontitusi Amerika Serikat :

"Regular elections to the National Assembly shall be held within sixty days prior to the expiration of the term of the current Assembly. Procedures for elections to the National Assembly Assembly shall be prescribed by law. The date of elections shall be fixed by Presidential decree. The first session of a newly elected National Assembly shall convene on the second Thursday following the elections of at least two thirds of the total number of Deputies. Until the election of the total number of Deputies. Until the election of the President of National Assembly, its meetings shall be chaired by the Deputy who is most senior in age."

"The regular sessions of the National Assembly shall convene twice per year from the second Monday of September to the second Wednesday of December and from the first Monday of February to the second Wednesday of June. The sittings of the National Assembly shall be open to the public. Closed door sittings may be convened by a resolution of the National Assembly."

Disamping itu, dalam perkembangan pemikiran dan praktik penafsiran hukum di dunia akhir-akhir ini, telah berkembang pula berbagai corak dan tipe baru dalam penafsiran hukum dan konstitusi di berbagai negara. Oleh karena itu, pendapat-pendapat yang biasa kita diskusikan di berbagai fakultas hukum di tanah air juga perlu memperhatikan dinamika perkembangan di dunia ilmu hukum pada umumnya. Oleh sebab itu, berbagai pandangan para sarjana mengenai ragam metode penafsiran itu, perlu kita himpun da kita sarikan sebagaimana mestinya.

Selain ke-9 teori penafsiran tersebut diatas, dapat pula dikemukakan adanya pendapat Utrecht mengenai penafsiran undang-undang :

1. Penafsiran menurut arti kata atau istilah (taalkundige interpretasi)

Hakim wajib mencari arti kata dalam undang-undang dengan cara membuka kamus bahasa atau meminta keterangan ahli bahasa. Kalaupun belum cukup, hakim harus mempelajari kata tersebut dalam susunan kata-kata kalimat atau hubungannya dengan peraturan-peraturan lainnya. Cara penafsiran ini, menurut Utrecht, yang pertama ditempuh atau usaha permulaan untuk menafsirkan. ${ }^{29}$

${ }^{29}$ Utrecht, Pengantar Dalam Hukum Indonesia, disadur dan direvisi oleh Moh. Saleh Djindang, cet. XI, PT. (Jakarta : Ichtiar Baru, 1983), hlm. 208. 


\section{Penafsiran Historis (historis interpretatie)}

Cara penafsiran historis ini, menurut Utrecht, ${ }^{30}$ dilakukan dengan (i) menafsirkan menurut sejarah hukum (rechtshistorische interpretatie), dan; (ii) menafsirkan menurut sejarah penetapan suatu ketentuan (wetshistorische interpretatie). Penafsiran menurut sejarah, menurut Utrecht, merupakan penafsiran luas atau mencakup penafsiran menurut sejarah penetapan. Kalau penafsiran menurut sejarah penetapan dilakukan dengan cara mencermati laporan-laporan perdebatan dalam perumusannya, suratsurat yang dikirim berkaitan dengan kegiatan perumusan, dan lain-lain, sedangkan penafsiran menurut sejarah hukum dilakukan menyelidiki asal naskah dari sistem hukum yang pernah diberlakukan, termasuk pula meneliti asal naskah dari sistem hukum lain yang masih diberlakukan di negara lain. ${ }^{31}$

Bagi hakim, menurut Scolthen, makna penafsiran historis berdasarkan kebutuhan praktik. Pada umumnya yang penting bagi hakim ialah mengetahui maksud pembuat naskah hukum yang ditetapkan. Hukum bersifat dinamis dan perkembangan hukum mengikuti perkembangan masyarakat. Oleh karena itu, makna yang dapat diberikan kepada suatu kata dalam naskah hukum positif sekarang berbeda dengan maknanya pada waktu ditetapkan. Oleh sebab itu pula, penafsiran menurut searah hakikatnya hanya merupakan pedoman saja. ${ }^{32}$ Akan tetapi, penafsiran historis tidak hanya menelaah risalah sebagai story perumusan naskah, tetapi juga menelaah sejarah sosial, politik, ekonomi, dan social event lainnya ketika rumusan naskah tersebut dibahas.

3. Penafsiran sistematis

Penafsiran sistematis merupakan penafsiran menurut sistem yang ada dalam rumusan hukum itu srndiri (systematische interpretative). Penafsiran sistematis juga dapat terjadi jika naskah hukum yang satu dan naskah hukum yang lain, di mana keduanya mengatur hal yang sama, dihubungkan dan dibandingkan satu sama lain. Jika misalnya yang ditafsirkan itu adalah pasal dari suatu undang-undang, maka ketentuanketentuan yang sama, apalagi satu asas dalam peraturan lainnya, harus dijadikan acuan. ${ }^{33}$

${ }^{30}$ Pendapat Utrecht ini sangant mirip dengan pendapat Visser"t Hoft yang pada nantinya akan diuraikan secara tersendiri.

${ }^{31}$ Utrecht, Op. Cit., hlm.209

${ }^{32}$ Ibid., hlm. 210-211.

${ }^{33}$ Ibid., hlm. 212-213. 
4. Penafsiran sosiologis

Menurut Utrecht, setiap penafsiran undang-undang harus diakhiri dengan penafsiran sosiologis agar keputusan hakim dibuat secara sungguhsungguh sesuai dengan keadaan yang ada dalam masyarakat. Utecht mengatakan bahwa hukum merupakan gejala sosial, maka setiap peraturan memiliki tugas sosial yaitu kepastian hukum dalam masyarakat. Tujuan sosial suatu peraturan tidak senantiasa dapat dipahami dari katakata yang dirumuskan. Oleh karena itu, hakim harus mencarinya. Penafsiran sosiologis merupakan jaminan kesungguhan hakim dalam membuat keputusan, oleh karena keputusannya dapat mewujudkan hukum dalam suasana yang senyatanya dalam masyarakat. ${ }^{34}$

5. Penafsiran otentik atau resmi (authentieke atau officiele interpretatie)

Penafsiran otentik ini sesuai dengan tafsir yang dinyatakan oleh pembuat undang-undang (legislator) dalam undang-undang itu sendiri. ${ }^{35}$ Misalnya, arti kata yang dijelaskan dalam pasal atau dalam penjelasannya. Jikalau ingin mengetahui apa yang dimaksud dalam suatu pasal, maka langkah pertama adalah lihat penjelasan pasal itu. Oleh sebab itu, penjelasan undang-undang selalu diterbitkan tersendiri, yaitu dalam Tambahan Lembaran Negara, sedangkan naskah undang-undang diterbitkan dalam Lembaran Negara.

Sementara itu, Visser't Hoft mengemukakan 7 (tujuh) model penafsiran hukum, yaitu : ${ }^{36}$

1. Penafsiran Gramatikal atau Interpretasi Bahasa

Dalam model ini, penafsiran grmatikal yang dimaksud mempunyai pengertian yang sama sebagaimana telah dikemukakan sebelumnya.

\section{Penafsiran Sistematis}

Makna formulasi sebuah kaidah hukum atau makna dari sebuah istilah yang ada di dalamnya ditetapkan lebih jauh dengan mengacu pada hukum sebagai sistem. Langkah yang dilakukan yaitu dengan mencari makna kata-kata yang terdapat di dalam suatu peraturan yang ada kaitannya dan melihat pula kaidah-kaidah lainnya. Menurut Visser't Hoft, dalam sebuah sistem hukum yang menitikberatkan pada kodifikasi, maka merujuk pada pada sistem undang-undang atau kitab undang-undang merupakan hal yang biasa. Perundang-undangan adalah sebuah sistem. Ketentuan-ketentuan yang ada didalamnya saling berhubungan dan sekaligus keterhubungan tersebut dapat menentukan suatu makna. Akan

${ }^{34}$ Ibid., hlm. 216.

35 Ibid., hlm. 217

${ }^{36} \mathrm{Ph}$. Visser't Hoft, Op. Cit. 
tetapi, dalam tatanan hukum yang tidak terkodifikasi, merujuk pada sistem dimungkinkan sepanjang karakter sistematis dapat diasumsikan atau diandaikan.

3. Penafsiran Sejarah Undang-undang

Penafsiran dengan cara merujuk pada sejarah penyusunannya, membaca risalah, catatan pembahasan oleh komisi-komisi dan naskah-naskah lain yang berhubungan dengan pembahasan termasuk surat menyurat yang berhubungan dengan penyusunan suatu undang-undang.

4. Penafsiran Sejarah Hukum

Penafsiran dengan cara menentukan arti suatu rumusan norma hukum dapat memperhitungkan sejarah isi norma atau pengertian hukum dengan cara mencari keterkaitan dengan pendapat penulis-penulis, atau konteks kemasyarakatn masa lalu.

5. Penafsiran Teleologis

Maksudnya yaitu menafsirkan dengan cara mengacu kepada formulasi norma hukum menurut tujuan dan jangkauannya. Fokus perhatian dalam menafsirkan adalah fakta bahwa pada norma hukum mengandung tujuan atau asas yang menjadi dasar sekaligus mempengaruhi interpretasi.

6. Penafsiran Antisipatif

Menurut Visser't Hoft. Metode penafsiran ini dilakukan dengan cara merujuk RUU yang sudah disiapkan untuk dibahas atau sedang dibahas dalam parlemen. Dengan cara ini sebenarnya hakim melihat ke masa yang akan datang (forward looking). Dengan perkataan lain, hakim dapat saja berpendirian bahwa penafsiran terhadap norma hukum yang dilakukannya didasarkan atas penelahaan dari sudut pandang hukum baru.

7. Penafsiran Evolutif-Dinamis

Penafsiran ini dilakukan karena ada perubahan pandangan masyarakat dan situasi kemasyarakatan. Makna yang diberikan kepada suatu norma bersifat mendobrak perkembangan setelah diberlakukannya hukum tertentu. Salah satu cirri penting penafsiran ini ialah pengabaian maksud pembentuk undang-undang. Makna obyektif atau aktual maupun subyektif dari suatu norma sama sekali tidak berperan lagi.

Jazim Hamidi, dengan mengutip pendapat Sudikno Mertokusumo, A. Pitio, Achmad Ali, dan Yudha Bhakti, mencatat 11 (sebelas) macam metode penafsiran hukum, yaitu : ${ }^{37}$

${ }^{37}$ Jazim Hamidi, Hermeneutika Hukum, cet. I, (Yogyakarta : UII Press 2005), hlm. 53-57. 
1. Interpretasi Gramatikal, menafsirkan kata-kata dalam undang-undang sesuai kaidah bahasa dan kaidah hukum tata bahasa.

2. Interpretasi Historis, yaitu penafsiran sejarah undang-undang dan sejarah hukum.

3. Interpretasi Sistematis, menafsirkan undang-undang sebagai sebagai bagian dari keseluruhan sistem perundang-undangan.

4. Interpretasi Sosiologis atau Teleologis, makna undang-undang dilihat berdasarkan tujuan kemasyarakatannya, sehingga penafsiran dapat mengurangi kesenjangan antara sifat positif hukum dengan kenyataan bukum.

5. Interpretasi Komparatif, menafsirkan dengan cara membandingkan dengan berbagai sistem hukum.

6. Interpretasi Fituristik, menafsirkan undang-undang dengan cara melihat pula RUU yang sedang dalam proses pembahasan.

7. Interpretasi Restriktif, membatasi penafsiran berdasarkan kata yang maknanya sudah tertentu.

8. Interpretasi Ekstensif, menafsirkan dengan melebihi batas hasil penafsiran gramatikal.

9. Interpretasi Otentik, penafsiran yang hanya boleh dilakukan berdasarkan makna yang sudah jelas dalam undang-undang.

10. Interpretasi Interdisipliner, menggunakan logika penafsiran lebih dari satu cabang ilmu hukum.

11. Interpretasi Multidisipliner, menafsirkan dengan menggunakan tafsir ilmu lain di luar ilmu hukum.

Dalam hubungannya dengan penafsiran, dapat dikembangkan pula pendapat Jerzy Wroblewski yang mengembangkan meta-teori rasionalistik dan relativistik mengenai penafsiran dan implementasi undang-undang (legal statutes), yaitu teori tentang interpretasi atau teori tentang ideologi-ideologi penafsiran undang-undang. ${ }^{38}$

Dalam penafsiran dikenal pula adanya tipe-tipe argumen-argumen yang digunakan, (McCormick and Summers, 1991), yaitu :39

a. The argument from ordinary meaning, atau menggunakan argument makna umum yang berlaku dalam masyarakat.

${ }^{38}$ Jerzy Wroblewsky, dalam Alexander Peczenik, "Kinds of Theory of egal Argumentation", http://www. Ivr2003/Peczenik_Argumentation.htm.

39 Alexander Peczenik, Op. Cit. 
b. The argument from technical meaning, atau menggunakan argument teknis yang dipakai dalam istilah teknis.

c. The argument from contextual-harmonization.

d. The argument from precedent.

e. The argument from analogy.

f. The argument from relevant principles of law.

g. The argument from history.

b. The argument from purpose.

i. Substansive reasons.

$j$. The argument from intention.

William Eskrige dalam bukunya mengembangkan teori dinamika penafsiran undang-undang (dynamic theory of statutory interpretation) dengan menyatakan, “... that statutory interpretation changes in response to new political aligments, new interpreters, and new ideologies". Sementara Aulis Aarnio mengatakan, tugas dogmatik hukum adalah menginterpretasikan dan mensistematisasi normanorma hukum (The tasks of legal dogmatic are interpretation and systematization of legal norms). Dua kebutuhan pokok dalam penafsiran hukum menurutnya, adalah rasionalitas dan akseptabilitas. Sistematisasi bermaksud melakukan reformulasi norma-norma hukum dalam pengungkapan abstrak dalam hubungannya terhadap konsep-konsep dasar.

Sistematisasi adalah pembawa tradisi hukum. Dikatakan oleh Aulis Aarnio, interpretasi adalah aktivitas hermenutik yang menjustifikasi dalam hubungannya terhadap audien hukum, yang dikarakterisasikan sebagai esensia secara relativistik dalam pengertian mengakui kemungkinan perselisihan tentang evaluasi. Dworkin mengatakan :

"The adjudicative principle of integrity instructs judges to identify legal rights and duties, so far as possible, on the assumption that they were all created by a single author - the community personified - expressing a coherent conception of justice and fairness. (...) According to law as integrity, propositions of law are true if they figure in or follow from the principles of justice, fairness, and procedural due process that provide the best constructive interpretation of the community's legal practice".

Selanjutnya Dworkin mengatakan pula :

"Law as integrity (...) holds that people have as legal rights whatever rights are sponsored by the principles that provide the best justification of legal practice as a whole. Dworkin claim's ... that the true theory of legal practice is the theory that's puts legal practice in its best light. By "best lights" Dworkin means a measure of desirability or goodness : 
the true theory of legal practice, says Dworkin, potrays the practiceat its most desirable. Now why would that be the case? What's between the desirability of a theory and its truth?".

Terlepas dari segala macam metode atau teori penafsiran di atas, suatu hal yang perlu menjadi perhatian serius adalah bahwa hukum, baik yang tertulis maupun tidak tertulis, adalah konsep yang berasal dari kata-kata yang dahulunya diucapkan oleh satu, dua, atau lebih banyak orang yang kemudian disusun dalam kalimat. Tiap-tiap perkataan itu di dalamnya mengandung beberapa atau bahkan banyak makna, sehingga hukum dalam konteks norma sesungguhnya adalah simbol-simbol atau tanda-tanda yang disusun sedemikian rupa dalam bentuk pasal yang dituangkan dalam rumusan Undang-Undang Dasar, undang-undang, atau peraturan-peraturan tertulis lainnya.

Hukum yang tertulis dalam batas-batas tertentu dapat ditelusuri maksudnya, meskipun adakalanya ketika harus diterapkan pada suatu kasus dalam banyak situasi dan kondisi sosial ternyata tidak mudah. Korupsi, misalnya, adalah kata yang memerlukan kecermatan dalam penerapannya meskipun sudah jelas rumusannya. Demikian pula kata "jasa” dalam konteks hukum, apakah orang yang menerima imbalan atas jasanya membantu memperkenalkan kepada panitera kepala pengadilan dapat dianggap terlibat dalam kejahatan, jikalau ternyata orang diperkenalkan itu kemudian menyuap panitera tersebut.

Dalam penerapan hukum selain penafsiran, seperti telah diuraikan sebelumnya, dikenal pula kegiatan penemuan hukum atau metode konstruksi. Metode ini digunakan ketika juris (hakim, penuntut umum, dan pakar hukum) menghadapi ketiadaan dan kekosongan aturan untuk menyelesaikan persoalan konkrit. Penemuan hukum secara lebih umum pada prinsipnya adalah reaksi terhadap situasi-situasi problematikal yang dipaparkan dalam peristilahan hukum. Tujuannya adalah memberi jawaban terhadap persoalan-persoalan dan mencari penyelesaian sengketa konkret. ${ }^{40}$ Tentang penemuan hukum ini sebagian pakar memisahkannya dari penafsiran hukum, sebagian lagi menganggapnya termasuk metode penafsiran hukum.

Konstruksi hukum menurut teori dan praktek dapat dilakukan dengan 4 (empat) metode, yaitu :

1. Analogi atau Metode argumentum per analogium.

Cara kerjanya, metode ini diawali dengan pencarian esensi umum suatu peristiwa hukum yang ada dalam undang-undang. Esensi yang diperoleh kemudian dicoba terhadap peristiwa yang dihadapi. Apakah peristiwa itu memiliki kesamaan prinsip dengan prinsip yang terdapat dalam esensi umum tadi. Umpamanya apakah seseorang yang "memancing belut" dapat diberi sanksi, sementara larangan yang tertera di sudut kolam berbunyi "dilarang memancing ikan".

${ }^{40}$ J.A. Pointer, Op. Cit. 


\section{Metode Argumentum a Contrario.}

Ini digunakan jika ada ketentuan undang-undang yang mengatur hal tertentu untuk peristiwa tertentu, sehingga untuk hal lain yang sebaliknya dapat ditafsirkan sebaliknya.

3. Metode Penyempitan Hukum. Misalnya, "perbuatan melawan hukum" dapat dipersempit artinya untuk peristiwa tertentu yang termasuk perbuatan melawan hukum, sehingga terdapat peristiwa yang dapat dikatagorikan perbuatan melawan hukum.

4. Fiksi Hukum.

Menafsirkan atau menginterpretasi, menurut Arief Sidharta, intinya adalah kegiatan mengerti atau memahami. ${ }^{41}$ Hakikat memahami sesuatu adalah yang disebut filsafat hermenentika atau metode memahami atau metode interpretasi dilakukan terhadap teks secara holistik dalam bingkai keterkaitan antara teks, konteks, dan kontekstualisasi. ${ }^{42}$ Memahami sesuatu adalah menginterpretasi sesuatu agar memahaminya. Dalam hubungan ini Gadamer mengatakan, seperti dikutip oleh Arief Sidharta, ${ }^{43}$ Ilmu Hukum adalah sebuah eksamplar Hermenentika in optima forma, yang diaplikasikan pada aspek kehidupan bermasyarakat. Sebab, dalam menerapkan Ilmu Hukum ketika menghadapi kasus hukum, maka kegiatan interpretasi tidak hanya dilakukan terhadap teks yuridis, tetapi juga terhadap kenyataan yang menyebabkan munculnya masalah hukum itu sendiri.

Dalam melakukan interpretasi tentu saja antara penafsir dan teks yang hendak ditafsirkan terdapat perbedaan waktu bertahun-tahun bahkan puluhan atau ratusan tahun. Oleh karena itu, ketika melakukan interpretasi acapkali muncul dua sudut pandang yang berbeda antara teks yang hendak ditafsirkan dengan pandangan penafsir sendiri. Kedua pandangan itu kemudian diramu dengan berbagai aspek yang dipedomani oleh penafsir, yaitu keadilan, kepastian hukum, prediktabilitas, dan kemanfaatan.

Titik tolak hermeneutika adalah kehidupan manusiawi dan produk budayanya, termasuk teks-teks hukum yang dihasilkan olehnya. ${ }^{44}$ Gregory Leyh mengatakan, hermeneutika hukum adalah merekonstruksikan kembali dari seluruh problema hermeneutika dan kemudian membentuk kembali kesatuan hermeneutika secara utuh, di mana ahli hukum dan teologi bertemu dengan para ahli humaniora. ${ }^{45}$ Tujuan hermeneutika hukum itu adalah untuk menempatkan perdebatan kontemporer tentang penafsiran atau interpretasi hukum di dalam kerangka hermeneutika pada umumnya. ${ }^{46}$

\footnotetext{
${ }^{41}$ B. Arief Sidharta, dalam kata pengantar, Jazim Hamidi, Op. Cit., hlm. Xi-xv

${ }^{42}$ Hamidi, Op. Cit., hlm. 45.

${ }^{43}$ Ibid., hlm. Xiii.

${ }^{44}$ Ibid., hlm. 39.

${ }^{45}$ Ibid., hlm. 42.

${ }^{46}$ Ibid., hlm. 45.
} 
Dalam hubungan dengan penafsiran atau interpretasi, Alexander Peezenick menyatakan, "... statements are partly a result of the author's philosophical background, partly a useful tool for political debate" ${ }^{47}$ Pandangan konvensional dalam penafsiran undang-undang menganggap bahwa pengadilan harus berupaya menemukan tujuan atau maksud dari pembuat undang-undang (the farmer's intent). Penafsiran demikian sejalan dengan pandangan bahwa proses pembentukan undang-undang didominasi oleh kesepakatan nilai-nilai di antara berbagai kelompok kepentingan. Bagi pembentuk undang-undang, kesepakatan adalah produk tawar menawar (political bargain).

Metode serupa juga digunakan dalam penafsiran perjanjian-perjanjian perdata. Proses penemuan maksud pembentuk undang-undang, bagaimanapun, lebih sulit ketimbang menemukan maksud yang melatarbelakangi kontrakkontrak perdata, sebab badan pembuat undang-undang memiliki cirri kemajemukan. Pernyataan-pernyataan pribadi anggota badan pembentuk undang-undang tidak bisa secara otomatis dianggap pengungkapan pandangan mayoritas yang paling mempengaruhi suatu undang-undang. Pendukung kelompok-kelompok kepentingan boleh jadi menyembunyikan tujuan yang sebenarnya dari legislasi.

Penafsiran konstitusi, di Jerman misalnya, menurut Leibholz, Mahkamah Konstitusi Jerman adalah mahkamah yang bebas, membantu dengan memberikan jaminan kebebasan bagi pengadilan dan menjalankan fungsi administrasi hukum dalam pengertian materiel. Putusan-putusan Mahkamah Konstitusi Jerman disebut hukum yang sesungguhnya (real law). Keputusankeputusannya merupakan putusan yang murni bersifat hukum, di mana hakimhakim tidak melakukan penemuan-penemuan di luar batas substansi hukum dasar, melainkan mengungkapkan makna essensi hukum sebagai suatu pendirian atau sikap. Hukum konstitusi tertulis juga tunduk pada perubahan, dan Mahkamah Konstitusi disebut pada tahap tertentu berperan dalam perubahanperubahannya melalui pelaksanaan fungsi-fungsi yudisialnya.

${ }^{47}$ Posner, Op. Cit., hlm. 576-577. The conventional view of statutory interpretation is that the court endeavors (mengusabakan) to discover (menemukan) and effect to the intentions of the enacting legislature. This is consisten with viewing the legislative process as one dominated by deals (kesepakatan) among intrest groups; in this view legislative enactment is a bargained sale and the same methods used in the interpretation of ordinary private contracts are appropriate (tepat). The process od discovering legislative intent, however, is more difficult than that of discovering the intent bebind an ordinary contract because of the plural nature of enacting body. The statements of individual legislators, even of legislative committees, cannot automatically be assumed to express the views of the "silent majority" that necessary for enactment. Furthermore, the proponents (pendukung) of interest groups legislation may conceal the true objective of the true objective of the legislation in order to increase the informant cost of opponents.yet to some extent at least, this reticense is selfdefeating. What is concealed from the public is likely to be concealed from the judges, leading the construct a public interest rationale that may blunt the redistributive thrust of the legislation (but sometimes exaggerate it-when?). 


\section{Pembentukan Undang-undang}

Di dalam Undang-undang No.12 Tahun 2014 tentang Pembentukan Peraturan Perundang-undangan merupakan pelaksanaan dari perintah Pasal 22A Undang-Undang Dasar Negara Republik Indonesia Tahun 1945 yang meyatakan bahwa "Ketentuan lebih lanjut mengenai tata cara pembentukan undang-undang diatur lebib lanjut dengan undang-undang". Akan tetapi ruang lingkup materi muatan undang-undang ini diperluas lagi, tidak saja berbicara tentang undang-undang saja tetapi mencakup pula Peraturan Perundang-undangan lainnya, selain UndangUndang Dasar Negara Republik Indonesia Tahun 1945 dan Ketetapan Majelis Permusyawaratan Rakyat.

Banyak terjadi penafsiran hukum tentang ketentuan pasal 7 ayat (1) huruf c Undang-undang Nomor 12 Tahun 2011 yang menyatakan bahwa jenis dan hierarki Peraturan Perundang-undangan terdiri atas :
a. Undang-Undang Dasar Negara Republik Indonesia Tahun 1945;
b. Ketetapan Majelis Permusyawaratan Rakyat;
c. Undang-undang/ Peraturan Pemerintah Pengganti Undang-undang;
d. Peraturan Pemerintah;
e. Peraturan Presiden;
f. Peraturan Daerah Provinsi;
g. Peraturan Daerah Kabupaten/Kota;

Penelitian ini dibuat untuk mencoba menganalisa tentang bunyi Pasal 7 ayat (1) huruf c Undang-undang Nomor 12 tahun 2011 tentang Pembentukan Peraturan Perundang-undangan, yang menyatakan bahwa Undang-undang mempunyai kedudukan yang sama dengan Perppu. Undang-Undang Dasar 1945 telah mengamanatkan pada pasal 22 ayat (1) bahwa "dalam hal ibwal kegentingan yang memaksa, Presiden berhak menetapkan peraturan pemerintah pengganti undang-undang." Penetapan PERPPU yang dilakukan oleh Presiden ini juga tertulis dalam Pasal 1 ayat (4) Undang-undang No.12 Tahun 2011 tentang Pembentukan Peraturan Perundang-undangan yaitu "Peraturan Pemerintah Pengganti Undangundang adalah Peraturan Perundang-undangan yang ditetapkan oleh Presiden dalam ibwal kegentingan yang memaksa." Jika dilihat dari hierarki peraturan perundang-undangan sesuai dengan Pasal 7 ayat (1) undang-undang Nomor 12 tahun 2011 tentang Pembentukan Peraturan Perundang-undangan diatas kita dapat mengetahui bahwa UU dan Perppu itu memiliki kedudukan yang sama atau sederajat atau sejajar, akan tetapi jika kita merujuk pada suatu konseptual ilmu perundangundangan bahwa antara UU dan Perppu mempunyai pemaknaan penafsiran hukum yang berbeda. Kedudukan UU dan PERPPU di dalam Undang-undang Nomor 12 tahun 2011 mempunyai kedudukan yang sama, sederajat akan tetapi ada kalanya dapat dikatakan tidak sama dengan Undang-undang karena belum disetujui oleh Dewan Perwakilan Rakyat (DPR). 
Mengarah pada teori menurut Djokosoetono, konstitusi yang menjadi objek kajian hukum tata negara material dan formil juga mempunyai tiga arti, yaitu dalam arti materiel, dalam arti formil, dan dalam naskah yang terdokumentasi. Menurutnya undang-undang dapat dilihat : ${ }^{48}$

a. Dalam arti materiel, algemene verbindende voorschriften;

b. Dalam arti formil, yaitu bahwa undang-undang itu telah mendapat persetujuan (wilsovereen-stemming) bersama antara Pemerintah dan DPR; dan

c. Dalam arti naskah hukum yang harus terdokumentasi (gedocumenteerd) dalam Lembaran Negara supaya bersifat bewijsbaar atau dapat menjadi alat bukti dan stabil sebagai suatu kesatuan rujukan.

\section{Pembentukan PERPPU}

Kegentingan yang memaksa sebagai dasar pembentukan suatu PERPPU tidaklah sama pengertiannya dengan keadaan bahaya yang dimaksud dalam Pasal 12 yang juga seperti Pasal 22 (yang tidak diubah setelah Perubahan UUD 1945), meskipun keduanya merupakan penjabaran yang lebih konkret dari kondisi abnormal pada suatu sistem ketatanegaraan tertentu. Penentuan syaratsyarat dan akibat keadaan bahaya dalam Pasal 12 jelas memerlukan keterlibatan DPR untuk ditetapkan dengan undang-undang, sedangkan kegentingan yang memaksa dalam Pasal 22 sangat tergantung subyektifitas Presiden, meskipun nantinya tergantung pula pada persetujuan obyektif para wakil rakyat di DPR. ${ }^{49}$

Pasal 12 UUD 1945 disebutkan bahwa : "Presiden menyatakan keadaan bahaya. Syarat-syarat dan akibatnya keadaan bahaya ditetapkan dengan undangundang," sedangkan di dalam Pasal 22 UUD 1945 disebutkan bahwa :

(1). Dalam hal ihwal kegentingan yang memaksa, Presiden berhak menetapkan Peraturan Pemerintah sebagai pengganti undang-undang.

(2). Peraturan Pemerintah itu harus mendapat persetujuan Dewan Perwakilan Rakyat dalam persidangan yang berikut.

(3). Jika tidak mendapat persetujuan, maka peraturan pemerintah itu harus dicabut.

Menanggapi hal tersebut diatas memberikan gambaran tentang penafsiran pasal 12 UUD 1945 yang menyatakan bahwa dalam suatu waktu Presiden dapat menetapkan bahwa Negara dalam keadaan bahaya maka Presiden menetapkan hal tersebut melalui ketetapan yang dituangkan dalam Undang-

${ }^{48}$ Djokosoetomo, Hukum Tata Negara, Himpunan oleh Harun Alrasid, hlm. 47-48 (Jakarta: Ghalia Indonesia, 1982).

49 Jimly Asshidiqie, Hukum Tata Negara Darurat .Jakarta : PT. RajaGrafindo Persada, 2008), hlm., 12-13. 
undang, sedangkan jika kita bandingkan dengan ketentuan pasal 22 ayat (1) UUD 1945 menyatakan bahwa dalam hal ikhwal kegentingan yang memaksa Presiden berhak menetapkan peraturan pemerintah sebagai pengganti undangundang.

Unsur kegentingan memaksa harus menunjukan dua ciri umum, yaitu adanya krisis dan kemendesakkan, oleh Bagir Manan suatu keadaan krisis ditafsirkan dengan adanya gangguan yang menimbulkan kegentingan dan bersifat mendadak (a grave and sudden disturbunse). Sedangkan kemendesakkan, diartikan sebagai keadaan yang tidak diperhitungkan sebelumnya dan memuat suatu tindakan segera tanpa menunggu permusyawaratan telebih dahulu. Atau telah ada tanda-tanda permulaan yang nyata dan menurut nalar yang wajar (reasonableness), apabila tidak diatur segera akan menimbulkan gangguan baik bagi masyarakat ataupun terhadap jalannya pemerintahan. ${ }^{50}$

Sejalan dengan Bagir Manan, kegentingan yang memaksa menurut Jimly Asshidiqie lebih ditekankan pada aspek kebutuhan hukum yang bersifat mendesak atau urgensi yang terkait dengan waktu yang terbatas. ${ }^{51}$ Kemudian ditambahkan bahwa terdapat tiga syarat materiil untuk menetapkan PERPPU, yaitu $^{52}$ :

1. Ada kebutuhan yang mendesak untuk bertindak (reasonable necessity);

2. Waktu yang tersedia terbatas atau terdapat kegentingan waktu (limited time);

3. Tidak tersedia aternatif lain atau menurut penalaran yang wajar alternative lain diperkirakan tidak dapat mengatasi keadaan, sehingga penetapan PERPPU merupakan satu-satunya cara untuk mengatasi keadaan tersebut (beyond reasonable doubt).

Melengkapi dan menutup ajaran-ajaran para ahli tersebut, MK sebagai penafsir konstitusi ${ }^{53}$ melalui Putusan No. 138/PUU-VII/2009, menafsirkan frasa kegentingan yang memaksa dalam pasal 22 UUD 1945 dengan tiga (3) syarat yaitu :

50 Bagir Manan, Lembaga Kepresidenan, Yogyakarta, Penerbit Gama Media, 1999, hlm., 158-159.

${ }^{51}$ Jimly Asshiqie, Op. Cit., hlm. 207.

${ }^{52}$ Bahkan menurut Jimly Asshidiqie, di samping berfungsi sebagai pengawal dan penafsir konstitusi, MK juga sebagai pengawal demokrasi (the guardian and the sole interpreter of the constitution, as well as the guardian of the process of the process of the democratization). Jimly Asshidiqie, Perkembangan dan Konsolidasi Lembaga Negara Pasca Reformasi, Jakarta : Sekretaris Jenderal dan Kepaniteraan Mahkamah Konstitusi RI, 2006, hlm., 154-155.

${ }^{53}$ Jimly Asshidiqie, Op. Cit., hal 211. 
a. Adanya keadaan yaitu kebutuhan mendesak untuk menyelesaikan masalah hukum secara cepat berdasarkan undang-undang;

b. Undang-undang yang dibutuhkan tersebut belum ada sehingga terjadi kekosongan hukum, atau ada undang-undang tetapi tidak memadai;

c. Kekosongan hukum tersebut tidak dapat diatasi dengan cara membuat undang-undang secara prosedur biasa karena akan memerlukan waktu yang cukup lama sedangkan keadaan-keadaan yang mendesak tersebut perlu kepastian untuk diselesaikan.

Di tinjau dari hal tersebut di atas, beberapa waktu yang lalu ketika pada masa kePresidenan Susilo Bambang Yudhoyono telah mengeluarkan dan telah ditandangani yaitu Perppu No. 1 Tahun 2014 tentang Pemilihan Gubernur, Bupati dan Walikota dan Perppu No. 2 tahun 2014 tentang Pemerintahan Daerah. Perppu No. 1 Tahun 2014 berisi tentang aturan mengenai pelaksanaan pemilihan gubernur, bupati, dan walikota oleh rakyat dan mencabut UU No. 22 Tahun 2014, sedangkan perppu No. 2 Tahun 2014 merupakan beleid perubahan atas UU No. 23 Tahun 2014 tentang Pemerintahan Daerah yang menghapus wewenang DPRD memilih kepala daerah.

Pasal 20 ayat (2) UUD NRI 1945 menentukan bahwa "setiap rancangan undang-undang dibahas oleh Dewan Perwakilan Rakyat dan Presiden untuk mendapatkan persetujuan bersama". Seperti telah dikemukakan sebelumnya, bahwa dalam pembentukan undang-undang DPR tidak bisa jalan sendiri tanpa ada persetujuan dari Presiden. Kedua-duanya, baik DPR maupun Presiden harus setuju, tidak bisa DPR setuju tetapi Presiden tidak setuju. Keduanya harus berjalan seiring untuk setuju bersama. Jadi, meskipun kekuasaan pembentukan undang-undang berada di tangan DPR, tetapi tanpa ada persetujuan dari pemerintah, maka suatu rancangan undang-undang tidak akan menjadi undangundang.

Frasa "persetujuan bersama" dalam pasal ini tidak selalu bermakna untuk "setuju", tetapi bisa juga dimaknakan untuk "tidak setuju”. Ketidak setujuan bisa saja terjadi manakala antara DPR dan Pemerintah tidak sepakat mengenai substansi yang diatur dalam rancangan undang-undang. Makna "tidak setuju" secara tersirat terdapat dalam ketentuan pasal 20 ayat (3) UUD NRI 1945 yang menentuan bahwa "jika rancangan undang-undang itu tidak mendapat persetujuan bersama, rancangan undang-undang itu tidak boleh diajukan lagi dalam persidangan Dewan Perwakilan Rakyat masa itu."

Berdasarkan ketentuan pasal 20 ayat (5) UUD NRI 1945 rancangan undang-undang yang telah disetujui bersama antara DPR dan Presiden tetapi tidak disahkan oleh Presiden, maka dalam waktu 30 hari semenjak rancangan undang-undang tersebut disetujui, rancangan undang-undang tersebut sah menjadi undang-undang dan wajib diundangkan. Ketentuan pasal 20 ayat (5) UUD NRI 1945 tersebut kemudian dijabarkan dalam pasal 38 undang-undang tentang Pembentukan Peraturan Perundang-undangan. Pengesahan rancangan 
undang-undang tersebut dilakukan oleh Presiden dengan membubuhkan tandatangan dalam jangka waktu paling lambat 30 hari. Jadi, apabila Presiden diam, maka Presiden dianggap telah menyetujui rancangan undang-undang tersebut.

Secara logika, mestinya suatu rancangan undang-undang yang telah mendapat persetujuan bersama antara DPR dan Presiden (menteri yang mewakili) tidak perlu sampai tidak ditandatangani oleh Presiden, karena persetujuan tersebut sebetulnya sudah ada sejak Presiden melalui Amanat Presiden (AmPres) menunjuk menteri yang terkait untuk mewakili Presiden dalam pembahasan rancangan undang-undang tersebut di DPR. Seyogyanya apabila dalam pembahasan di DPR tidak terjadi kata sepakat mengenai suatu masalah antara DPR dan Pemerintah, menteri yang mewakili berkonsultasi terlebih dahulu dengan Presiden. Dengan demikian ketidaksepakatan itu seharusnya terjadi pada waktu pembahasan rancangan undang-undang di DPR, bukan melalui cara Presiden tidak menandatangani rancangan undang-undang yang sudah mendapatkan persetujuan bersama.

Melihat hal tersebut tampaklah jelas bahwa makna dari lahirnya sebuah undang-undang memiliki perbedaan yang cukup fundamental dengan lahirnya sebuah PERPPU, dimana undang-undang muncul dari sebuah rancangan undang-undang kemudian haruslah mendapatkan kata sepakat atau mendapatkan kesepakatan secara bersama antara legislatif (DPR) dan eksekutif (Presiden) terlebih dahulu, sedangkan PERPPU lahir dari adanya penafsiran eksekutif (Presiden) sebagaimana yang telah tertuang di dalam pasal 22 UUD NRI 1945 yaitu tentang suatu hal ihwal yang memaksa.

\section{Kesimpulan}

Sebagaimana yang telah diuraikan secara ringkas diatas maka penafsiran dalam ilmu hukum sebenarnya sangat diperlukan dalam pembentukan peraturan perundang-undangan dimana kegiatan interpretasi atau penafsiran merupakan aktifitas yang inheren terdapat dalam keseluruhan sistem bekerjanya hukum dan ilmu hukum itu sendiri. Sehingga tidak perlu lagi adanya ketentuan pasal-pasal dalam sebuah UUD NRI yang dapat memunculkan multitafsir dan tentang tumpah tindihnya kewenangan antar lembaga-lembaga negara dapat dihindari, serta dalam penegakkan supremasi hukum (law enforcement) dapat dilaksanakan secara optimal sehingga tidak dapat lagi memunculkan celah bagi kepentingankepentingan politik yang ingin mengambil keuntungan dari adanya multitafsir dalam ketentuan peraturan perundang-undangan. 


\section{Daftar Pustaka}

Alder, John and Peter English, Constitusional and Administrative Law, London : Macmillan, 1989.

Alen, A, Handboek van het Belgisch Staatsrecht, Antwerpen, Kluwer Rechtswettenschappen, 1995.

Appadoral. A, The Substance of Politics, Oxford University Press, Oxford India Paperbacks, 2005.

Asshiddiqie, Jimly, Gagasan Kedaulatan Rakyat dalam Konstitusi dan Pelaksanaannya di Indonesia, Jakarta, 1994. . Hukum Tata Negara dan Pilar-Pilar Demokrasi, cet, kedua. Jakarta, Konstitusi Press, 2005.

Konstitusi dan Ketatanegaraan Indonesia Kontemporer, Penerbit The Biography Institute, Jakarta, 2007, hlm., 131.

. Konstitusi dan Konstitusionalisme Indonesia, Jakarta, Konpress, 2005. - Perkembangan dan Konsolidasi Lembaga Negara Pasca Reformasi, Jakarta, Sekretariat Jenderal dan Kepaniteraan MK RI, 2006. Jimly Asshidiqie, Teori \& Aliran Penafsiran Hukum Tata Negara, cet. I, (Ind. Hill Co., Jakarta ,1997, hal., 17-18.

Manan, Bagir, Lembaga Kepresidenan, Penerbit Gama Media, Yogyakarta, 1999, hal., 158-159.

Fahmal, Muin, Peran Asas-asas Umum Pemerintahan Yang Layak Dalam Mewrujudkan Pemerintahan Yang Bersih, Penerbit Kreasi Total Media, Yogyakarta, 2008, hlm., 100.

Juhaefah, Imran, Hal Ibwal Kegentingan Yang Memaksa Sebagai Landasan Pembentukan Peraturan Pemerintah Pengganti Undang-Undang, Disertasi, Pascasarjana Universitas Muslim Indonesia, Makassar, 2011, hlm., 2.

Van Vollenhoven, Christian, H.D. Tjenk Willink \& Zoon, (Haarlem: Martinus Nyhoof \& Gravenhage), 1934.

Djokosoetomo, Hukum Tata Negara, Himpunan oleh Harun Alrasid, Ghalia Indonesia, Jakarta, 1982, hal., 47-48.

Kelsen, Hans, General Theory of Law and State, New York, 1961, hal., 188-191. Hamidi, Jazim, Hermeneutika Hukum, cet. I, UII Press 2005, Yogyakarta, hal., 53-57.

Moh Kusnardi dan Harmaily Ibrahim, Pengantar Hukum Tata Negara Indonesia, cet. Kelima, Pusat Studi Hukum Tata Negara Fakultas Hukum Universitas Indonesia, Jakarta, 1983, hal., 22.

Moh. Kusnardi dan Bintan R. Saragih, Ilmu Negara, edisi revisi, Gaya Media Pratama, Jakarta, 2000, hal.,10.

O.Hood Philips, Paul Jackson and Patricia Leopold, Constitutional and Administration Law, $8^{\text {th }}$ edition, (Sweet and Maxwell), London, 2001, hal. 4.

Ph. Visser't Hoft, Penemuan Hukum, judul asli Rechtsvinding, diterjemahkan oleh B. Arief Sidharta, (Laboratorium Hukum FH Univ Parahyangan), Bandung, 2001, hal., 25. 
Utrecht, Pengantar Dalam Hukum Indonesia, disadur dan direvisi oleh Moh. Saleh Djindang, cet. XI, PT. Ichtiar Baru, Jakarta, 1983, hal., 208.

Wirjono Prodjodikoro, Asas-Asas Hukum Tata Negara di Indonesia, cet. Keenam,

PT. Dian Rakyat, Jakarta, 1989, hal., 2.

\section{Perundang-undangan}

Undang-Undang Dasar Negara Republik Indonesia 1945 Dalam Satu Naskah.

Undang-Undang Nomor 12 Tahun 2011 Tentang Pembentukan Peraturan Perundang-undangan.

Undang-Undang Nomor 22 Tahun 2014 Tentang Pemilihan Gubernur, Bupati Dan Walikota.

Undang-Undang Nomor 23 Tahun 2014 tentang Pemerintahan Daerah.

Peraturan Pemerintah Pengganti Undang-Undang Nomor 1 Tahun 2014 Tentang Pemilihan Gubernur, Bupati Dan Walikota.

Peraturan Pemerintah Pengganti Undang-Undang Nomor 2 Tahun 2014 Tentang Pemerintahan Daerah. 